\title{
Evaluation of Biofertilization on Growth and Quality of Moringa oleifera Grown on Sandy Soil
}

\author{
Salah, G.Ali ${ }^{1}$; O. A. O. Saad ${ }^{2}$; Omar, H.M.Hassan ${ }^{1 *}$ \\ ${ }^{1}$ Botany and Microbiology Department, Faculty of Science Al-Azhar University Assiut, Egypt. \\ ${ }^{2}$ Agricultural Microbiology Department, Faculty of Agricultural, Minia University, Minia, Egypt. \\ *corresponding author e-mail: elhassan661@yahoo.com
}

Received on: 19/4/2020

Accepted on: 23/5/2020

\begin{abstract}
Moringa oleifera was treated with four microorganisms (Azotobacter sp, Bacillus subtilis, Pseudomonas fluorescence and Trichoderma. harzianum) as biofertilizers in individual or in combinations inoculants to determine the growth and quality of such plant. The obtained results showed that treatment by microorganis ms in combination is the best choice in improving of Moringa growth and its quality after 60 days of seeds planting, followed by Pseudomonas fluorescence, T.S (fertilizer) and Azotobacter since they were $91.92,86.00,85.58$ and $80.50 \mathrm{~cm} / \mathrm{plant}$ respectively, whereas T. harzianum and B. subtilis, showed moderate effect in increasing of plant growth compared with the control. Treatments by biofertilizing microorganisms in combination exhibited highest values for both fresh and dry weights, N, P and K percentage since they were (18.21 for fresh weight, 5.03 dry weight, $4.50 \mathrm{~N} \% 0.27 \mathrm{P} \%$ and $2.57 \mathrm{~K} \%$ ) compared with individual treatments and control (untreated plants).
\end{abstract}

KEYWORDS: Moringa, Biofertilizers, Plant Growth-promoting, Rhizobacteria, Phytohormones, greenhouse conditions.

\section{INTRODUCTION}

Microorganisms flourished among us for centuries and they play a protruding role in our day-to-day life in 24 hours (Choi, 2013). They are present in air we breathe, water we drink, and the food we eat, inside us and even in the vacuum of outer space (Zhang et al., 1995). The term PGPMs encompasses a wide range of bacteria and fungi working on plant growth and survival. These microorganisms live in close contact to the plant root zone that is defined as the rhizosphere at which the roots are thought to be a major source of nutrients for them (Carmen and Roberto 2011). Microorganisms have long been used in cultivation of crops due to their various beneficial effects to provide nutrients and induce resistance in adverse conditions (Vessey, 2003). Moringa ( $M$. oleifera) plant is used in different ways as; fertilizer (seed cake), blue dye (wood), (Emmanuel et al., 2011), foliar nutrient (juice expressed from the leaves), green manure (from leaves), honey (flower nectar), medicine (all plant parts), gum (from tree trunks), honey and sugar cane juice-clarifier (powdered seeds), water purification (powdered seeds). Moringa plant is an exceptionally nutritious tree with a variety of potential uses (Fahey, 2005 and Saini et al., 2016). Chemical fertilizers are one of the problems of human societies today because of the resulting environmental pollution so the use of biological fertilizers, can reduce the chemical fertilizer used and helping in achieving sustainability of farms (Arafa et al., 2009 and Kumar et al. 2013;
2015). This study was carried out to determine the effects of treatments by biofertilizing microorganisms on growth and macro-nutrients contents of Moringa plant under greenhouse conditions.

\section{Materials and methods:}

2.1.Cultivar: Moringa seeds (Moringa oleifera) were obtained from nursery of the Faculty of Agriculture, Minia University, Egypt.

2.2.Tested microorganisms: Trichoderma harzianum was isolated from the rhizosphere of tomato plants located in Minia governorate, Egypt and identified at Mycological center Assiut University, Egypt. Bacillus subtilis and Pseudomonas fluorescence were obtained from Agricultural Microbiology Department, Faculty Agriculture Minia University, Egypt. Commercial fertilizer (T.S) was obtained from the Agricultural Society of Abu Qurqas city, Minia Governorate. Azotobacter spp. isolates were isolated from the rhizosphere of tomato plants grown in different regions of Minia Governorate, Egypt as follow: Samalout, Abu Qurqas, Minia and Mallawi. After purification, isolates were tested towards to study their efficiency to nitrogen fixation by growing in modified Ashby's medium (Abdel-Malek and Ishak 1968). These isolates were incubated at $30^{\circ} \mathrm{C}$ for $2-5$ days. 
2.3.Determination of nitrogenase activity of bioagents isolates: The nitrogen fixing capability of the isolates was achieved using the ambient assay of nitrogenase activity ac cording to Postage (1972), the most efficient nitrogen-fixing bacterial isolates of Azotobacter spp. were selected for further study.

2.4.Experimental Soil: Sandy soil was collected from the region of Jabal Balansoura, Abu Qurqas city, Minia Governorate. For greenhouse experiments, each soil from the top $15 \mathrm{~cm}$ was air dried, thoroughly mixed, with bird droppings in the rate of 3:1 (w/w) and passed through $2 \mathrm{~mm}$ sieve. The physical and chemical analyses of the used soil are presented in Table (1).

Table 1. Physical and chemical analyses of the experimental soils

\begin{tabular}{cc}
\hline Measurements & Values \\
\hline Sand (\%) & 94.7 \\
Silt (\%) & 2.2 \\
Clay (\%) & 3.1 \\
Soil Texture & Sand \\
PH & $\mathbf{8 . 0}$ \\
E.C.m.mhos /cm & $\mathbf{2 . 6 5}$ \\
K me/100g & $\mathbf{0 . 6 6}$ \\
CaCO3 (\%) & 5.0 \\
Total N (ppm) & $\mathbf{3 5 . 0}$ \\
\hline Available P $(\mathbf{p p m})$ & $\mathbf{4 4 . 0}$
\end{tabular}

2.5.Inocula preparation:

Bacterial strains were grown on nutrient agar medium (peptone $5.0 \mathrm{~g}$, beef extract $3.0 \mathrm{~g}$, yeast extract $2.0 \mathrm{~g}$, agar $20 \mathrm{~g}$, distilled water to $1 \mathrm{~L}$ ). For routine use, a single colony w as transferred to $250 \mathrm{ml}$ flasks containing nutrient broth (peptone $5.0 \mathrm{~g}$, beef extract $3.0 \mathrm{~g}$, yeast extract $2.0 \mathrm{~g}$, distilled water to 1 L) and grown aerobically in flasks on a rotary shaker (95 rpm) for $48 \mathrm{hr}$ at $28^{\circ} \mathrm{C}$. then the bacterial suspension was diluted in sterile distilled water to final concentration of $1 \times 10^{8} \mathrm{CFU} / \mathrm{ml}$, and the resulting suspensions were used to treat seeds Moringa plants described by ( Al- Azawi et al, 2012). Inocula of the fungal strain was grown on PDA medium which contains from potato (scrubbed and diced), 200g; dextrose $20 \mathrm{~g}$ agar $15 \mathrm{~g}$, distilled water to $1 \mathrm{~L}$. The medium was supplemented with chloramphenicol $(250 \mathrm{mg} / \mathrm{ml})$ as a bacteriostatic agent (Riker Riker, 1936). After incubation we take disc from 5 days of old culture on PDA medium were prepared by growing in sterilized conical flasks $(1000 \mathrm{ml})$ containing barley medium which contains from ( 75 barley seeds, $25 \mathrm{~g}$ clean sand, sucrose $2 \mathrm{~g}$, yeast $0.1 \mathrm{~g}$ and water $100 \mathrm{ml}$ ) and incubated at $27^{\circ} \mathrm{C}$ for 15 days.

2.6.Green house experiments: A pot experiment was conducted under greenhouse conditions of Faculty of Agriculture Minia University, in the summer for Moringa plant. The cultivation process was carried out during 2017 and 2018 growing seasons, using plastic pots of $30 \mathrm{~cm}$ in diameter and $35 \mathrm{~cm}$ in depth. A portion of $7 \mathrm{~kg}$ sterilized soil was placed in each pot and seven replicates for each of the following treatments were conducted. Each replicate contains 3-5 seeds for Moringa treatments, seeds were chosen to be similar in size and weight as much as possible and washed repeatedly with sterile water (Rovira, 1959). Suitable amount of seeds were immersed for 20 minutes in the appropriate cell suspension which contained $5 \%$ of Arabic gum to the microbe adhesion surfaces according to the treatment of PGPR bacteria containing $1 \times 10^{8}$ colony forming unit $(\mathrm{CFU}) / \mathrm{ml}$ following the protocol described by (Fages, 1990) and (El-Mohamedy and Ahmed, 2009). In the case using a mixed culture of PGPR organisms, equal portions of the cells suspensions were thoroughly mixed and similarly used for seeds inoculation (Azotobacter spp., B. subtilis, Ps. fluorescence and T. harzianum).

\subsection{Experimental treatments}

1- Inoculation with Azotobacter (AZ14).

2- Inoculation with B. subtilis.

3- Inoculation with Ps. fluorescence.

4- Inoculation with T. harzianum.

5- Inoculation with the mixture of bioagents.

6- T.S (fertilizer).

7- Control (without any treatment)

2.8.Determinations

Determination of macro elements content

(a)Total nitrogen: Total nitrogen was determined by micro- kjeldahl method modified by (piper, 1950).

(b)Total phosphorus: Total phosphorus was determined colorimetric ally by the reduction of the phosphomolybdate complex stannous chloride in the sulfuric acid system according to (Jackson, 1958).

(c)Total potassium: Total potassium $w$ as determined by a flame photometer as described by (Peterburgski, 1968).

2.9. Statistical analysis: Data collected were statistically analyzed by the analysis of variance using the general linear model (GLM) procedure of statistical analysis system (SAS, 2006). The following statistical model Completely Randomized Design using the following models.

- $\quad \mathbf{Y i j}=\boldsymbol{\mu}+\mathbf{T i}+\mathbf{E} \mathbf{i j}$ where

- $\quad \mathbf{Y i j}=$ The observation value of the concerned trait.

- $\boldsymbol{\mu}=$ The overall mean for the concerned trait.

- $\mathbf{T i}=$ The effect of inoculation treatments (with or without).

- $\mathbf{E i j}=$ Experimental error. 
Salah, G.Ali et al., 2020

Significant differences among treatments were separated by Duncan`s multiple range tests (Duncan, $1955)$ at level $5 \%$ only when F-value were significantly different at level $5 \%$. The differences were expressed as follow:

- $\mathrm{NS}=$ Not signific ant $(\mathrm{p} \geq 0.05)$

- $\square=$ significant $(\mathrm{p} \leq 0.05)$

- $\square \square=$ =Highly signific ant $(\mathrm{p} \leq 0.01)$
3. Results and Discussion:

3.1.Nitrogenase activity of Azotobacter isolates

Twenty isolates of Azotobacter were isolated randomly from rhizosphere and rhizoplane of tomato plant were tested for their efficiency for nitrogen fixation using the ambient assay of nitrogenase activity and the most efficient of four isolates of Azotobacter (AZ14, AZ13, AZ10, AZ12), then these isolates were subjected to further studies as shown in table (2)

Table 2. Nitrogenase activity (nanomoles $\mathrm{C}_{2} \mathrm{H}_{4} \mathrm{ml}^{-1} \mathrm{hr}^{-1}$ ) of Azotobacter isolates.

\begin{tabular}{cccc}
\hline & \multicolumn{2}{c}{ Azotobacter isolates } & \\
\hline Isolate No. & $\mathbf{N}_{\mathbf{2}}$-ase activity & Isolate No. & $\mathbf{N}_{\mathbf{2}}$-ase activity \\
\hline AZ1 & $\mathbf{2 2 . 4}$ & AZ11 & $\mathbf{0}$ \\
AZ2 & $\mathbf{1 9 . 1 8}$ & AZ12 & $\mathbf{4 3 . 1 5 * * *}$ \\
AZ3 & $\mathbf{1 4 . 7 5}$ & AZ13 & $\mathbf{4 8 . 1 1 * * *}$ \\
AZ4 & 19.82 & AZ14 & $\mathbf{6 8 . 5} * * *$ \\
AZ5 & $\mathbf{3 3 . 0 3}$ & AZ15 & $\mathbf{2 6 . 7 1}$ \\
AZ6 & $\mathbf{3 9 . 6 9}$ & AZ16 & $\mathbf{3 3 . 0 3}$ \\
AZ7 & $\mathbf{2 0 . 4}$ & AZ17 & $\mathbf{3 1 . 5}$ \\
AZ8 & $\mathbf{2 1 . 6 0}$ & AZ18 & $\mathbf{1 4 . 1 5}$ \\
AZ9 & $\mathbf{3 6 . 0 3}$ & AZ19 & $\mathbf{4 1 . 1 8}$ \\
AZ10 & $\mathbf{4 5 . 1 4 * * *}$ & AZ20 & $\mathbf{3 2 . 1 9}$ \\
\hline
\end{tabular}

3.2. Effect of bio-agents on plant height, fresh weight and dry weight of Moringa oleifera plant under greenhouse conditions during 2017 and 2018 growing seasons after 15 days:

Data in the Table (3) showed that the application of the mixture treatment $(\mathrm{AZ}+\mathrm{BS}+\mathrm{PF}+\mathrm{TH})$ of Moringa seeds grown in sandy soil gave the best results in increasing plant height (cm/plant) after 15 days of cultivation of Moringa seeds followed by T.S fertilizer and Ps. fluorescence since. These treatments recorded $38.00,35.50$ and $35.08 \mathrm{~cm} /$ plant respectively while, $T$. harzianum and $B$. subtilis showed the moderated effect however Azotobacter sp. recorded lowest value in increasing plant height as compared with the control. The same trend was obvious in case of mixture treatment which gave the highest values of both fresh and dry weight (g/plant), followed by Ps. fluorescence and

T.S fertilizer. These treatment rec oded $(2.14,0.90)$, $(2.08,0.79)$ and $(1.93,0.44) \mathrm{g} / \mathrm{plant}$, while treatment with $T$. harzianum and $B$. subtilis gave the moderate effect in increasing of fresh and dry weight ( $\mathrm{g} / \mathrm{plant}$ ). The lowest results in both fresh and dry weight (g/plant) were recorded by Azotobacter sp. as compared with the control. Generally, mixture treatments gave the highest values in enhancing growth parameters of Moringa plants. These results are in harmony with those reported by (Zehnder et al., 2001) who mentioned that the inoculation with mixture of PGPR for seeds of several crops and ornamental plants before planting enhanced growth characteristics and (Dobbelaere et al., 2003) who found that the inoculation with Azospirillum sp. resulted on increasing root and aerial parts dry weights of the PGPR inoculated plant during two seasons

Table 3. Effect of bio-agents on plant height, fresh weight and dry weight of Moringa oleifera plant under greenhouse conditions during 2017 and 2018 growing seasons after 15 days

\begin{tabular}{lccc}
\hline \multirow{2}{*}{ Bioagent } & Plant height $(\mathbf{c m})$ & Fresh weight $(\mathrm{gm})$ & Dry weight $(\mathrm{gm})$ \\
\cline { 2 - 4 } & $* *$ & $* *$ & $* *$ \\
\hline Azotobacter sp (AZ14) & $\mathbf{3 1 . 4 2}^{\mathrm{a}}$ & $\mathbf{1 . 5 5}^{\mathrm{a}}$ & $\mathbf{0 . 2 4}^{\mathrm{e}}$ \\
B. subtilis & $\mathbf{3 2 . 0 8}^{\mathrm{cd}}$ & $\mathbf{1 . 7 0}^{\mathrm{c}}$ & $\mathbf{0 . 2 6}^{\mathrm{e}}$ \\
Ps. fluorescence & $\mathbf{3 5 . 0 8}^{\mathrm{b}}$ & $\mathbf{2 . 0 8}^{\mathrm{a}}$ & $\mathbf{0 . 7 9}^{\mathrm{b}}$ \\
T. harzianum & $\mathbf{3 3 . 7 5}^{\mathrm{bc}}$ & $\mathbf{1 . 7 2}^{\mathrm{c}}$ & $\mathbf{0 . 4 3}^{\mathrm{c}}$ \\
Mixture (AZ+BS+PF+TH) & $\mathbf{3 8 . 0 0}^{\mathrm{a}}$ & $\mathbf{2 . 1 4}^{\mathrm{a}}$ & $\mathbf{0 . 9 0}^{\mathrm{a}}$ \\
T.S( fertilizer) & $\mathbf{3 5 . 5 0}^{\mathrm{b}}$ & $\mathbf{1 . 9 3}^{\mathrm{b}}$ & $\mathbf{0 . 4 4}^{\mathrm{c}}$ \\
Control & $\mathbf{2 7 . 7 5}^{\mathrm{e}}$ & $\mathbf{1 . 4 0}^{\mathrm{e}}$ & $\mathbf{0 . 1 9}^{\mathrm{f}}$ \\
\pm SE & $\mathbf{0 . 6 1 9}$ & $\mathbf{0 . 0 4 8}$ & $\mathbf{0 . 0 1 6}$ \\
\hline
\end{tabular}


3.3. Effect of bio-agents on plant height, fresh weight and dry weight of Moringa oleifera plant under greenhouse conditions during 2017 and 2018 growing seasons after 30 days

Data in the Table (4) indicated that the application of the mixture treatment of Moringa oleifera grow $\mathrm{n}$ in sandy soil gave the best results in increasing plant height $(\mathrm{cm} /$ plant $)$ after 30 days of cultivation of Moringa oleifera seeds followed by Ps fluorescence, Trichoderma harzianum, T.S (fertilizer), Azotobacter sp. (AZ14) and B. subtilis whereas. These treatments recorded 51.00, 46.75, $45.92,45.42,45.08$ and $42.83 \mathrm{~cm} /$ plant respectively as compared with the control in both seasons. The same trend was clear in case of mixture treatment which gave the highest values of both fresh and dry under greenhouse conditions during 2017 and 2018 growing seasons after 30 days

weight ( $\mathrm{g} /$ plant), followed by T.S (fertilizer), $T$. harzianum and Ps. Fluorescence. These treatments recorded $(4.21,1.13),(3.37,0.94),(3.05,0.62)$ and $(2.84,0.60) \mathrm{g} /$ plant while treatment with Azotobacter sp. (AZ14) and B. subtilis gave the moderate effect in increasing of fresh and dry weight (g/plant) these treatments recorded $(2.77,0.57)$ and $(2.62,0.53)$ as compared with the control. Generally, mixture treatments gave the highest values in enhancing growth parameters of Moringa plants. These results are in concord with those reported by (Tsuno et al. 2017) who reported that soybean roots secrete large amounts of soyasaponins (a new type of root exudate) during the vegetative emergence (VE) stage of growth.

Table 4. Effect of bio-agents on plant height, fresh weight and dry weight of Moringa oleifera plant

\begin{tabular}{|c|c|c|c|}
\hline \multirow[b]{2}{*}{ Bioagent } & Plant height $(\mathrm{cm})$ & Fresh weight (gm) & Dry weight (gm) \\
\hline & $* *$ & $* *$ & $* *$ \\
\hline Azotobacter sp. (AZ14) & $45.08^{a}$ & $2.77^{\mathrm{bcd}}$ & $0.57^{\mathrm{b}}$ \\
\hline B. subtilis & $42.83^{a}$ & $2.62^{\mathrm{cd}}$ & $0.53^{b c}$ \\
\hline Ps. fluorescence & $46.75^{a}$ & $2.84^{\mathrm{bcd}}$ & $0.60^{b}$ \\
\hline T. harzianum & $45.92^{\mathrm{a}}$ & $3.05^{b c}$ & $0.62^{b}$ \\
\hline $\operatorname{Mixture}(\mathrm{AZ}+\mathrm{BS}+\mathrm{PF}+\mathrm{TH})$ & $51.00^{a}$ & $4.21^{\mathrm{a}}$ & $1.13^{\mathrm{a}}$ \\
\hline T.S (fertilizer) & $45.42^{\mathrm{a}}$ & $3.37^{\mathrm{b}}$ & $0.94^{\mathrm{a}}$ \\
\hline Control & $34.67^{b}$ & $1.18^{\mathrm{e}}$ & $0.3^{\mathrm{c}}$ \\
\hline$\pm \mathbf{S E}$ & 2.596 & 0.232 & $\mathbf{0 . 0 7 9}$ \\
\hline
\end{tabular}

3.4.Effect of bio-agents on plant height, fresh weight and dry weight of Moringa oleifera plant under greenhouse conditions during 2017 and 2018 growing seasons after 60 days

The effect of bioagents treatment on growth characters was recorded in Table (5). Data clearly indicated that application with mixture of bioagents gave the best results in increasing plant height (cm/plant) after 60 days of Planting Moringa seeds followed by Ps. fluorescence, T.S (fertilizer) and Azotobacter sp. whereas, these treatments recorded $91.92,86.00,85.58$ and $80.50 \mathrm{~cm} /$ plant respectively. While, T. harzianum and B. subtilis, showed moderate effect in increasing plant height $(\mathrm{cm} /$ plant $)$ these treatments recorded 79.00 and $78.00 \mathrm{~cm} /$ plant compared with the control in both seasons 2017 and 2018. Also, mixture treatment gave the highest values of fresh weight ( $\mathrm{g} / \mathrm{plant}$ ) recorded 18.21 respectively. While treatments with T.S fertilizer, Azotobacter sp. (AZ14), B. subtilis, Ps. fluorescence and $T$. harzianum showed the moderate effect in increasing of fresh weight (g/plant) whereas, recorded $13.71,12.12,11.76,10.70$ and $10.32 \mathrm{~g} /$ plant as compared with the control. It is clear from the same data presented in the same table that the effect of bioagents treatments on dry weight showed that the mixture treatment gave the highest values of dry weight (g/plant), followed by T.S (fertilizer) these treatments recorded 5.03 and 3.41 respectively. While treatments with, B. subtilis, Ps. fluorescence and Azotobacter sp. (AZ14) showed the moderate effect in increasing of dry weight (g/plant) these treatments recorded 3.13, 3.12 and $2.92 \mathrm{~g} /$ plant. While the lowest results in dry weight (g/plant) were recorded by $T$. harzianum. Therefore, in general mixture treatment of bioagents gave the highest values in enhancing growth parameter of Moringa plants in both seasons 2017 and 2018. It is praiseworthy to mention that the increase of plant growth could be attributed to the role of both microorganisms present in dual inoculum used as fertilizer for plant. These has been increasing evidence that Azotobacter besides its role as $\mathrm{N}_{2}-$ fixer, it is produces phytohormones such as cytokinin, gibbereillic acids, vitamins and Psolubilizer. These factors often affect root development and morphology resulting in greater root surface area that facilitating the absorption nutrients and minerals. That is according to (Kennedy et al 2004) who found that inoculation of tomato roots with A. chroococcum, B. subtilis and $P$ s. fluorescens significantly increased plant grow th parameters and increased the total dry weight. 
Table 5. Effect of bio-agents on plant height, fresh weight and dry weight of Moringa oleifera plant under greenhouse conditions during 2017 and 2018 growing seasons after 60 days

\begin{tabular}{|c|c|c|c|}
\hline & Plant height $(\mathrm{cm})$ & Fresh weight (gm) & Dry weight (gm) \\
\hline Bioagent & $* *$ & $* *$ & $* *$ \\
\hline Azotobacter sp. (AZ14) & $80.50^{\mathrm{a}}$ & $12.12^{\mathrm{ab}}$ & $2.92^{\mathrm{bc}}$ \\
\hline B.subtilis & $78.00^{a}$ & $11.67^{\mathrm{ab}}$ & $3.13^{\text {bc }}$ \\
\hline Ps. Fluorescence & $86.00^{\mathrm{a}}$ & $10.70^{\mathrm{ab}}$ & $3.12^{\mathrm{bc}}$ \\
\hline T. harzianum & $79.00^{\mathrm{a}}$ & $10.32^{\mathrm{ab}}$ & $2.63^{\mathrm{c}}$ \\
\hline $\operatorname{Mixture}(\mathrm{AZ}+\mathrm{BS}+\mathrm{PF}+\mathrm{TH})$ & $91.92^{\mathrm{a}}$ & $18.21^{\mathrm{a}}$ & $5.03^{\mathrm{a}}$ \\
\hline T.S( fertilizer) & $85.58^{\mathrm{a}}$ & $13.71^{\mathrm{ab}}$ & $3.41^{b}$ \\
\hline Control & $43.00^{b}$ & $5.43^{b}$ & $1.29^{d}$ \\
\hline$\pm \mathbf{S E}$ & 6.849 & 3.066 & 0.234 \\
\hline
\end{tabular}

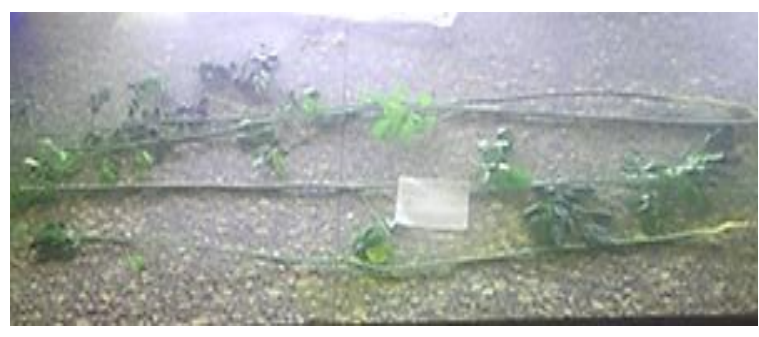

Fig 1. Effect of Ps.flourescence on moringa moringa after 60 days

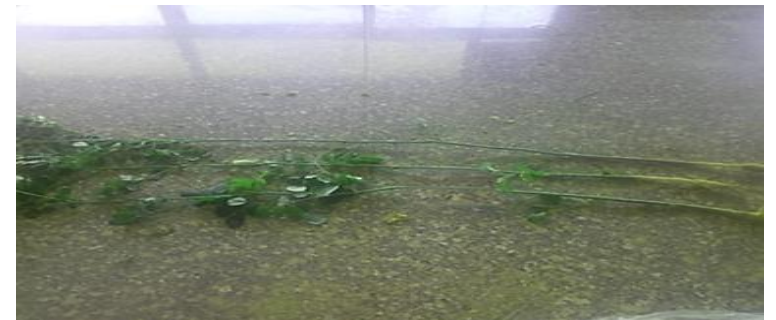

Fig 3. Effect of Mixtuer (Az,Bs,Th,Ps) on moringa after 60days

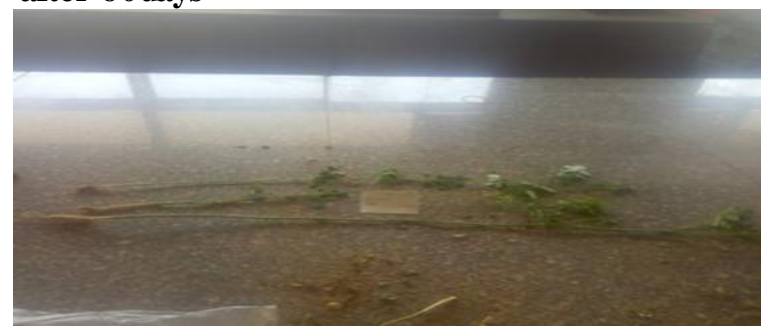

Fig 5. Fffect of $B$. subtilis on moringa after 60days

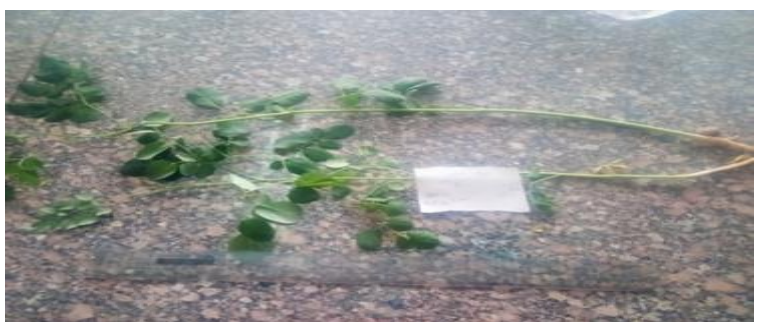

Fig 7. Fffect of T.S fertilizer on moringa after 60days

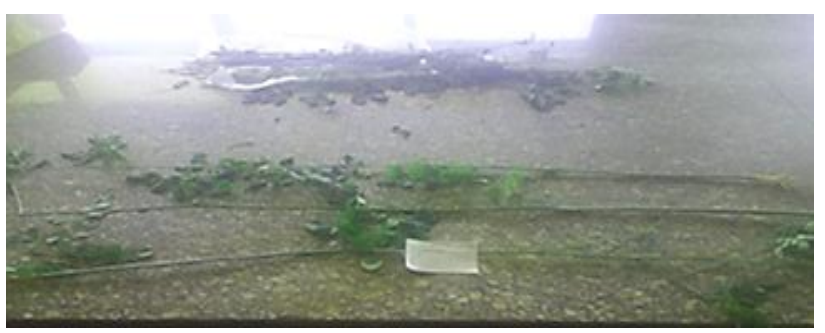

Fig 2. Effect of Azotobacter sp. on moringa after 60 days

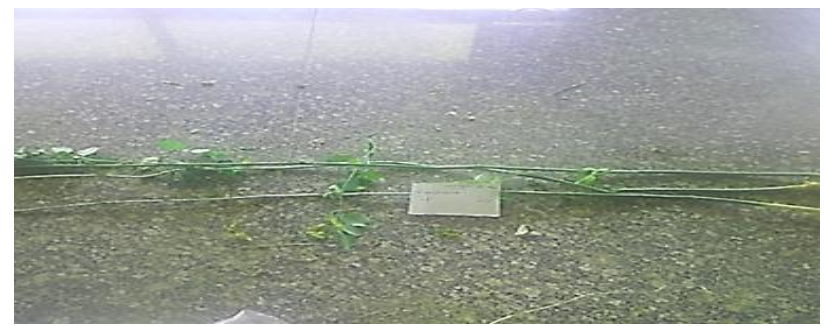

Fig 4. Effect of T.harzianum on moringa after 60days

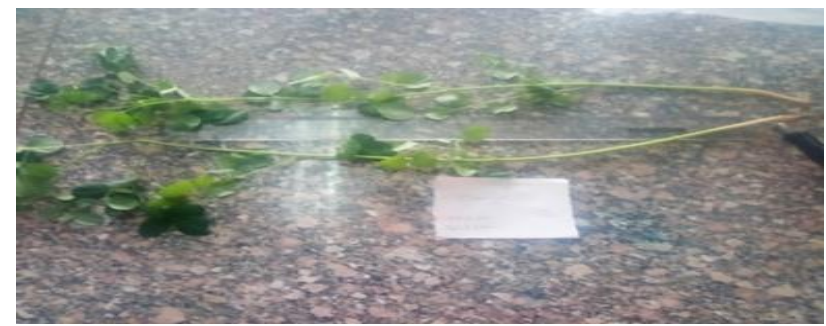

Fig 6. Moringa (control treatment) after 60days 
3.5.Effect of bioagents on nitrogen, phosphorus and potassium percentages of Moringa oleifera plants under greenhouse conditions during 2017 and 2018 growing seasons.

Data in Table (6) revealed that un-inoculated plants with bioagents (bacteria and fungi) recorded lower values of nitrogen, phosphorus and potassium rather than the inoculated one. The moringa plants inoculated with the mixture of bioagents (bacteria and fungi) significantly increased the total of macronutrients contents $(\mathrm{N}, \mathrm{P}$ and $\mathrm{K})$ of moringa shoots compared with individual inoculation with bioagents. On the other hand data in table (6) showed that the soil observed that soil without inoculations significantly decreased the macronutrient contents in moringa shoots. While, the soils that inoculation with the bioagents either individually or combined in the soil significantly increased NPK contents of moringa shoots compared to those planted in control. Results also, showed that application with the mixture of bioagents gave the best result in increasing percentage of nitrogen in the moringa plants followed by T.S (fertilizer) respectively these treatments recorded $4.50 \%$ and $4.44 \%$. While, treatments with Azotobacter sp. (AZ14), Ps. fluorescence and $B$. subtilis gave the moderate effect in increasing percentage of nitrogen contents of moringa plants whereas, these treatments recorded $3.21 \%$, and $2.01 \%$. On the other hand, T. harzianum had the lowest value in increasing nitrogen content as compared with the control plant during 2017 and 2018 growing seasons. Concerning the effect of bioagents on phosphorus and potassium contents, data in the same table exhibited that mixture of bioagents gave the highest value of phosphorus of moringa shoots compared to those planted in soil without inoculated by bioagents followed by $P S$. fluorescence, T.S (fertilizer) and Azotobacter sp. respectively these treatments recorded $0.27 \%$, $0.23 \%, 0.23 \%$ and $0.22 \%$. While treatments with $B$. subtilis and $T$. harzianum revealed the effect in increasing percentage of phosphorus in the moringa plants, where recorded both of them $0.19 \%$. On other hand data in the same table showed that mixture of bioagents treatment gave the best results in increasing potassium of moringa plants compared to those planted in the soil without inoculated (free) by PGPR followed by T.S (fertilizer), Azotobacter sp. and Ps. fluorescence these treatments recorded $2.57 \%, 2.39 \%, 2.37 \%$ and $2.33 \%$. While treatments with, $B$. subtilis and $T$. harzianum showed the moderate effect in increasing percentage of potassium in moringa plants as compared with the control during 2017 and 2018 growing seasons. These results are in accordance with those reported by (Sheng and He, 2006) who observed that plant growth promotion, increased yield, uptake of $\mathrm{N}$ and some other elements through PGPR inoculations which significantly promote growth and increased shoot and root growth of canola and sugar beet.

Hayat et al. (2010) Reported that Pseudomonas not only degrades organic nitrogenous compounds but also improves circulation of $\mathrm{N}$ and $\mathrm{P}$ in soil and in wheat signific antly increases root dry weight and harvest index. According to field visual observations, the plant grow th regulators resulted in vigorous development of greener and larger leaves, despite the unfavorable, very dry climatic conditions. Zayed, MS (2012). Noted that by results in growth improvement and nutritional quality were also found in case of Moringa oleifera using combination of different biofertilizers such as Azotobacter chroococcum, Azospirillium brasilense, Bacillus megatherium, Bacillus circulans, Pseudomonas fluorescence and Saccharomyces cerevisiae.

Table 6. Effect of bioagents on nitrogen, phosphorus and potassium percentages of Moringa oleifera plants under greenhouse conditions during 2017 and 2018 growing seasons

\begin{tabular}{|c|c|c|c|}
\hline Bioagent & $\mathrm{N} \%$ & P \% & K \% \\
\hline & *** & *** & $* *$ \\
\hline Azotobacter sp.(AZ14) & $3.21^{b}$ & $0.22^{\mathrm{abc}}$ & $2.37^{\mathrm{a}}$ \\
\hline B. subtilis & $2.01^{\mathrm{cd}}$ & $0.19^{b c}$ & $1.93^{\mathrm{ab}}$ \\
\hline Ps. Fluorescence & $2.62^{\mathrm{bc}}$ & $0.23^{\mathrm{ab}}$ & $2.33^{\mathrm{a}}$ \\
\hline T. harzianum & $1.91^{d}$ & $0.19^{b c}$ & $1.87^{\mathrm{ab}}$ \\
\hline Mixture $(\mathrm{AZ}+\mathrm{BS}+\mathrm{PF}+\mathbf{T H})$ & $4.50^{\mathrm{a}}$ & $0.27^{\mathrm{a}}$ & $2.57^{\mathrm{a}}$ \\
\hline T.S (fertilizer) & $4.44^{\mathrm{a}}$ & $0.23^{\mathrm{ab}}$ & $2.39^{\mathrm{a}}$ \\
\hline Control & $1.53^{\mathrm{d}}$ & $0.16^{\mathrm{c}}$ & $1.63^{b}$ \\
\hline$\pm \mathbf{S E}$ & 0.220 & 0.018 & 0.216 \\
\hline
\end{tabular}

\section{Conclusion:}

The results of this study, showed that the best results were obtained when application mixture of bio-agents: B. subtilis, Ps. fluorescence and $T$. harzianum in combination with nitrogen fixer of Azotobacter sp, as it showed an increasing vegetative growth characteristics of moringa plant (plant height, dry and fresh weight), and total 
nitrogen, phosphorous and potassium content compared to the fertilizer (TS) and the control under greenhouse conditions. Also the present study provide sufficient evidence to the recommended the use of the mixture of bioagents microorganisms $B$. subtilis, Pseudomonas fluorescence and $T$. harzianum in combination with nitrogen fixers of Azotobacter $s p$ is successful as biofertilizers for cultivated plants and soils. Also, biofertilization is alternative method for fertilization of most plants. Neverless, the biofertilization minimize the addition of inorganic chemical fertilizers and reduced the hazared effects of chemical fertilizers on human health and environment.

\section{REFERENCES:}

Abd El-Mlek Y, Ishac YZ (1968). Evaluation of methods used in counting Azotobacter. The Journal of Applied Bacteriology, 331(3), 267- 75.

Al-Azawi AQ, Nawar HH, Abdulla MI (2012). Biocontrol of Fusarium oxysporum f. sp. lycopersici by plant grow th promoting bacteria on tomato plant. the 2nd scientific conference the collage of Agriculture,57-64.

Arafa Rawhia AM, AbdEl-Ghany F, Bouthaina Sidkey M, Elshazly MM (2009). The beneficial Use of biofertilizers on growth and yield of wheat plants grown on sandy soil with or without nitrogen fertilization .Egyptian Journal of Biotechnology 32,127-146

Carmen B, Roberto D (2011) Soil bacteria support and protect plants against abiotic stresses. In: A Shanker Abiotic stress in plants mechanisms and adaptations, Pub InTech:143-170

Choi CQ (2013). Microbes Thrive in Deepest Spot on Earth. Live Sci. Retrieved 17 March2013.

Dobbelaere S, Vanderleyden J, Ok on Y (2003). Plant grow th-promoting effects of diazotrophs in the rhizosphere. Crit. Rev. Plant Sci., 22:107-149.

Duncan DB (1955). Multiple Range and Multiple F tests. Biometrics 11.1

El-Mohamedy RSR, Ahmed MA (2009). Effect of bio fertilizers and humic acid on control of dry root disease and improvement yield quality of mandarin (Citrus reticulate Blanco). Research Journal of Agricultural and Biological Science, 5(2): 127-137. Emmanuel SA, Zaku SG, Adedirin SO, Muazu T, Thomas SA (2011) Moringa oleifera seed-cake, alternative biodegradable and biocompatibility organic fertilizer for modern farming. Agric. Biol. J. N. Am. 2(9):1289-1292.

Fages J (1990). An optimized process for manufacturing an Azospirillum inoculant for crops. Applied microbiology and biotechnology, 32(4), 473-478.
Fahey JW (2005). Moringa oleifera: a review of the medical evidence for its nutritional, therapeutic and prophylactic properties part 1. Trees Life J. 1:5-20. Hayat R, Ali S, Amara U, Khalid R, Ahmed I (2010). Soil beneficial bacteria and their role in growth promotion: a review. Annual Review of Microbiology, 60: 579-598.

Jackson ML (1958). Soil chemical Analysis. P 216 prentice-Hall, Inc. Englewood Cliffs, N.J

Kennedy Ivan R, Choudhury ATMA, Kecskes Mihaly L (2004). Non-symbiotic bacterial diazotrophs in crop farming system. Their potential for plant grow th promotion be better exploited. Soil Biology and Biochemistry, Vol. 36: 1229 -1224.

Kumar K, Shukla UN, Kumar D, Pant AK, Prasad SK (2013). Bio-Fertilizers for organic agriculture. Popular Kheti 1 (4): 91 - 96.

Kumar A, Prakash J, Arora NK (2015). Biofertilizers: an alternative sources of chemical fertilizer for sustainable crops in 21st century. Pp: 28 - 31. Microbiology World Issue 10 Mar - Apr 2015, ISSN 2350 - 8774

Peterburgski AV (1968) Hand Book of Agronomic Chemistry. Kolas publishing House, Moscow, (in Russian), pp. 29-86.

Piper CS (1950) Soil and plant Analysis, The University of Adelaide press, Adelaide, Australia, 368p.

Postage JR (1972) The acetylene reduction test for nitrogen fixation. Meth. Microbiol., 66: 343

Riker J, Riker RS (1936). Introduction to Research in Plant Diseases. John Swift Co., New York.

Rovira AD (1959). Root excretion in relation to the rhizosphere effect. IV . Influence of plant species, age of plant, light, temperature, and calcium nutrition. Plant and soil, 11:53.

Saini RK, Manoj P, Shetty NP, Srinivasan K, Giridhar P (2016). Relative bioavailability of folate from the traditional food plant Moringa oleifera $\mathrm{L}$ as evaluated in a rat model. J Food Sci Technol. 53:511-520.

Sheng XF, He LY (2006). Solubilization of potassium-bearing minerals by a wild-type strain of Bacillus edaphicus and its mutants and increased potassium uptake by wheat". Canadian Journal of Microbiology, 52: 66-72.

Tsuno Y, Fujimatsu T, Endo K, Sugiyama A, Yazaki K (2017). Soyasaponins, a new class of root exudates in soybean (Glycine max). Plant Cell Physiol. 59, 366-375. [CrossRef] [PubMed]

Vessey JK (2003). Plant growth promoting rhizobacteria as biofertilizers. Plant Soil 255, 571586.

Zayed MS (2012). Improvement of growth and nutritional quality of Moringa oleifera using different biofertilizers. Annals of Agricultural Science, 57(1): 53-62. 
Zehnder GW, Murphy JF, Sikora EJ, Kloepper

JW (2001). Application of Rhizobacteria for induced resistance. Eur. J. Plant Pathol., 107:39-50.
Zhang KD, Bieger AD, Dillmann R, Gill M, Kerz

O, Klein A, Meinert H, Nawroth T, Risi S, Stride C (1995). ERA- experiment space biochemistry. Adv. Space Res., 16(8):119-129.

\title{
الملخص العربي
}

\author{
تقييم التسميد الحيوي على التمو والجودة لمورينجا اوليفيرا نامية فى الترية الرملية \\ صلاح الدين جمال الدين على'؛ عمر عبداللطيف عمر سعد'؛ عمر حسن محمد حسن'" \\ قسم النبات والميكروبيولوجي، كلية العلوم، جامعة الأزهر ، أسيوط، مصر ا

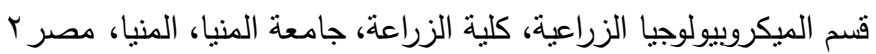

فى هذا البحث تمت معاملة مورينجا اوليفيرا بأربع كائنات دقيقة هي ( أزوتوباكتر، باسلس ساتلس، سيدوموناس فلورسنس و

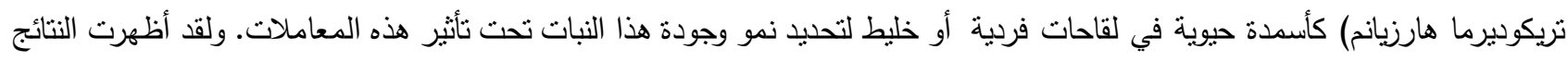

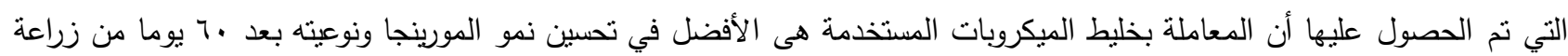

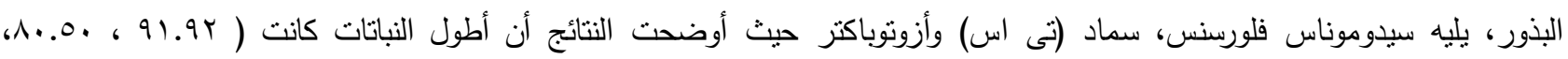

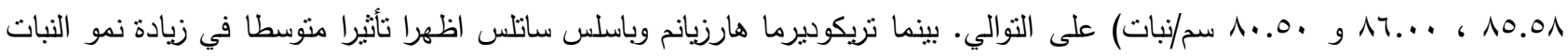

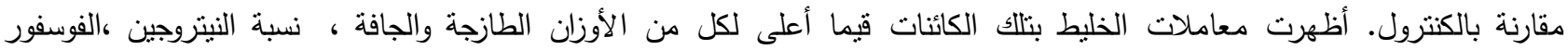

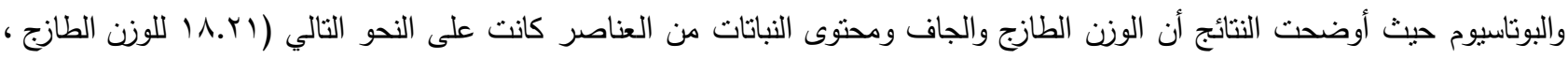

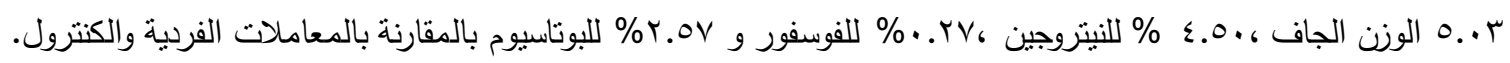
وفي ضوء النتائج المتحصل عليها من هذا البحث يمكن التوصية بالتوسع في استخدام تكنولوجيا النسميد الحيوي حيث ان ان عملية التنميد الحيوي تقلل من استخدام الأسمدة الكيميائية ذات الأثار الضارة على صلى صحة الإنسان والبيئة. 